\title{
Implantálható kardioverter-defibrillátor által sikeresen megszüntetett malignus kamrai ritmuszavar dystrophia myotonicában szenvedő betegben
}

\author{
Kupó Péter dr. ${ }^{1}$ - Fődi Eszter dr. ${ }^{1}$ - Debreceni Dorottya dr. ${ }^{1}$ \\ Pál Endre dr. ${ }^{2}$ - Faludi Réka dr. ${ }^{1}$ - Tényi Dalma dr. ${ }^{2}$ - Molnár Fanni dr. ${ }^{1}$ \\ Lovadi Emese dr. ${ }^{2}$ - Varga Dávid dr. ${ }^{2}$. Simor Tamás dr. ${ }^{1}$ \\ ${ }^{1}$ Pécsi Tudományegyetem, Általános Orvostudományi Kar, Klinikai Központ, Szívgyógyászati Klinika, Pécs \\ ${ }^{2}$ Pécsi Tudományegyetem, Általános Orvostudományi Kar, Klinikai Központ, Neurológiai Klinika, Pécs
}

A dystrophia myotonica (DM) multiszisztémás, autoszomális domináns módon öröklődő, többségében felnőttkori izombetegség, melynek incidenciája 1 : 8000. A betegség kapcsán fellépő izomszöveti degeneráció a harántcsíkolt izomszövet átépülése mellett a szívizomszövetet is érinti, ami fontos oki szerepet játszik az érintett betegek csökkent várható élettartamában. A DM-ben szenvedők halálozásának közel egyharmadáért a cardiovascularis okok tehetők felelőssé. Esetriportunkban egy 52 éves, korábban kritikus bradycardia és I. fokú atrioventricularis blokk miatt pacemakerimplantáción átesett, DM-mel diagnosztizált nőbeteg kardiológiai utánkövetését mutatjuk be. A hirtelen szívhalál rizikóstratifikációja céljából elvégzett invazív elektrofiziológiai vizsgálat során kamrafibrilláció lépett fel, így a korábban implantált pacemakerelektródák mellé sokkelektróda került beültetésre, a pacemakerkészüléket implantálható kardioverter-defibrillátorra (ICD) cseréltük. Az l éves ICD-kontrollvizsgálat során azt találtuk, hogy a beültetés óta 22, tartós kamrai tachycardiával járó epizód lépett fel, melyek közül a készülék valamennyit sikeresen terminálta. Az eset bemutatásával szeretnénk rámutatni arra, hogy a magas cardiovascularis rizikócsoportba tartozó DM-betegek azonosítása kiemelkedő fontosságú lehet a hirtelen szívhalál megelőzése érdekében.

Orv Hetil. 2021; 162(46): 1856-1858.

Kulcsszavak: dystrophia myotonica, invazív szív-elektrofiziológiai vizsgálat, rizikóbecslés, implantálható kardioverter-defibrillátor

\section{Successful termination of ventricular arrhythmias with implantable cardioverter defibrillator in a patient with myotonic dystrophy}

Myotonic dystrophy (DM) is one of the most frequent adulthood diseases of the skeletal muscles, which develops multisystemic features and shows autosomal dominant trait. In DM, tissue degeneration affects not only the skeletal, but the cardiac muscle, too. In one third of the patients, the cause of death is of cardiac origin. We report on our patient's case, who was diagnosed with DM at the age of 52, in whom episodes of critical bradycardia with first-degree atrioventricular block was detected, resulting in a pacemaker implantation. Invasive cardiac electrophysiological study was performed, during which ventricular fibrillation was registered. A shock electrode was added to the previously implanted pacemaker, enabling defibrillation in case of detection of a sustained ventricular arrhythmia. During the 1-year followup, 22 episodes of sustained ventricular tachycardia were identified, with the device successfully terminating the malignant arrhythmias. Our case shows that electrophysiological study and the succeeding implantation of an implantable cardiac defibrillator is highly important in identifying and terminating ventricular arrhythmias in high-risk DM patients.

Keywords: myotonic dystrophy, invasive cardiac electrophysiological study, risk stratification, implantable cardiac defibrillator

Kupó P, Fődi E, Debreceni D, Pál E, Faludi R, Tényi D, Molnár F, Lovadi E, Varga D, Simor T. [Successful termination of ventricular arrhythmias with implantable cardioverter defibrillator in a patient with myotonic dystrophy]. Orv Hetil. 2021; 162(46): 1856-1858.

(Beérkezett: 2021. április 9.; elfogadva: 2021. április 28.) 


\section{Rövidítések}

$\mathrm{AV}=$ atrioventricularis; $\mathrm{DM}=$ dystrophia myotonica $; \mathrm{EMG}=$ elektromiográfia; ENG = elektroneurográfia; ICD = (implantable cardioverter defibrillator) implantálható kardioverter-defibrillátor

A dystrophia myotonica (DM) multiszisztémás, autoszomális domináns módon öröklődő, többségében felnőttkori izombetegség, melynek incidenciája $1: 8000$ [1]. A betegség kapcsán fellépő izomszöveti degeneráció a harántcsíkolt izomszövet átépülése mellett a szívizomszövetet is érinti, ami fontos szerepet játszik a betegségben szenvedők csökkent várható élettartamában: a DM-mel diagnosztizált betegek halálozásának közel egyharmadáért kardiológiai okok felelősek [2-4]. A leggyakoribb kardiológiai manifesztációk a vezetési és szívritmuszavarok, melyek hátterében a szívizomszöveti átépülés miatt a szív ingerületkeltő és -vezető rendszerében bekövetkező változások állnak. Genetikailag igazolt DM esetén szükséges a kardiológiai szakvizsgálat, a szív esetleges érintettségének meghatározására [5]. A betegségnek két típusa ismert, az l-es típus (DMI) súlyosabb szervi tünetekkel jár. Közleményünkben a megfelelő kardiológiai rizikóbecslés fontosságát hangsúlyozzuk egy DMl-ben szenvedő beteg esetbemutatásával, akinek többször kialakult malignus kamrai ritmuszavarát sikeresen szüntette meg a korábban, cardialis rizikóbecslés eredményeként beültetésre került, implantálható kardioverter-defibrillátor (ICD).

\section{Esettanulmány}

Az 1956-ban született nőbeteg járási nehézségei 52 éves korában kezdődtek. A panaszok felléptét követően 10 évvel jelentkezett neurológiai szakrendelésen, mely során statusában alsó végtagi hypotrophia és paraparesis mutatkozott, közepes fokú proximalis és súlyos fokú distalis (dorsalflexiós) gyengeséggel, járásbizonytalansággal. A felső végtagokon szorítási myotoniát észleltünk. Elektromiográfiás (EMG-) vizsgálat során distalis túlsúlyú myotoniával társult myopathia igazolódott. Az elektroneurográfiás (ENG-) vizsgálat során kóros eltérés nem került leírásra. A beteg bal oldali musculus quadricepséből vett biopsziás mintában krónikus izomszövet-károsodás és dystrophiás jelek mutatkoztak, az elektronmikroszkópos vizsgálat súlyos rostkárosodást igazolt. A laboratóriumi vizsgálatok során emelkedett kreatin-kináz-érték mutatkozott $(605 \mathrm{U} / \mathrm{l})$. A genetikai vizsgálat során DMl igazolódott. Egy évvel a DM-diagnózis felállítását követően több alkalommal kritikus bradycardiát és I. fokú AV-blokkot - 264 ms-os PQ-intervallummal lehetett regisztrálni. Transthoracalis echokardiográfiás vizsgálat során megtartott bal kamrai ejekciós frakció, enyhe fokú koncentrikus balkamra-hypertrophia ábrázolódott. Az új keletű vezetési zavar miatt elvégzett koro- narográfia során szignifikáns szúkü̈let nem igazolódott, így - kizárva a ritmuszavar ischaemiaeredetû etiológiáját - kétüregû pacemakerimplantáció történt. Malignus kamrai ritmuszavar sem a pacemakerimplantáció előtt, sem az obszervációs időszakban nem fordult elő.

A beteg ezt követően tünetmentes volt, a kontrollechokardiográfiás vizsgálatok sem mutattak érdemi változást. Ezt követően a páciens 7 évvel később került ismételt kardiológiai osztályos felvételre cardialis rizikóstratifikáció céljából végzett invazív szív-elektrofiziológiai vizsgálat miatt, mely egy prospektív vizsgálatba való bekerülés kapcsán vált indokolttá. A felvételkor készült laborvizsgálat során érdemi eltérés nem mutatkozott. Invazív szív-elektrofiziológiai vizsgálata során katéterpozicionálás közben hemodinamikai megingást, eszméletvesztést okozó kamrafibrilláció lépett fel, emiatt defibrilláció vált szükségessé, ami sikeresen terminálta a ritmuszavart. Az ismert alapbetegségre, továbbá az invazív elektrofiziológiai vizsgálat során fellépő malignus kamrai ritmuszavarra való tekintettel a korábban implantált pacemakerelektródák mellé sokkelektróda került beültetésre, míg a korábbi pacemakerkészüléket pacemakerfunkció mellett defibrillátorfunkcióval is bíró ICD-re (ICD, Itrevia 7 DR-T; Biotronik, Berlin, Németország) cseréltük. A 1 éves ambuláns ICD-kontrollvizsgálat során a készülék eseményjelzője 22, lezajlott malignus arrhythmiával járó epizódot mutatott. A monomorf kamrai tachycardiás epizódokat a beültetett készülék 20 esetben felülvezérléssel („anti-tachycardia pacing”) szüntette meg, 2 alkalommal pedig defibrillátorsokk leadásával állt vissza a sinusrhythmus. A beteg a ritmuszavarokat szédülésként élte meg, hemodinamikai összeomlás egy alkalommal sem jelentkezett. Az ICDsokkütéseket követően a korábbi orvosi utasításokat figyelmen kívül hagyva nem jelentkezett soron kívül Klinikánkon. A béta-blokkoló dózisának maximalizálása történt, az ezt követő l évben nem lépett fel arrhythmia.

\section{Megbeszélés}

A DM gyakori, felnőttkori, multiszisztémás érintettséggel járó, autoszomális domináns módon öröklődő izombetegség [1]. A betegek első tünetei jellemzőon a második-negyedik évtizedben kezdődnek izomgyengeséggel és skeletalis myotoniával. A betegség multiszisztémás kórkép: a vázizomrendszer eltérései mellett ismertek légző́rendszeri (pharyngooesophagealis gyengeség, a légzőizmok gyengesége, alveolaris hypoventilatio), endokrinológiai (primer hypogonadismus, testicularis atrophia, inzulinrezisztencia), szemészeti (cataracta), gastrointestinalis (hasi fájdalom, puffadás, konstipáció, hasmenés) és kardiológiai (ingerületvezetési zavarok, pitvari és malignus kamrai ritmuszavarok, szívelégtelenség) manifesztációk is. A betegség relatív gyakorisága ellenére 2015-ig nem készült átfogó tanulmány és ajánlás a betegségben szenvedők kardiológiai kivizsgálására, 
rizikóbecslésére és gondozására vonatkozóan. A 2015ben megjelent szisztematikus közlemény összegezte az addig elérhető, DM-ben szenvedő betegek kardiológiai gondozása során nyert tapasztalatokat. Ezek alapján a szerzők a DM-betegek kardiológiai kivizsgálására vonatkozóan tették közzé javaslataikat, különös tekintettel a vezetési zavarokhoz és a ritmuszavarokhoz kapcsolódó szövődmények megelőzésére [5]. Az ajánlás szerint a DM-mel diagnosztizált betegeknél dokumentált tartós kamrai tachycardia vagy csökkent balkamra-funkció (ejekciós frakció <35\%) fennállása esetén ICD-beültetés szükséges, mindemellett invazív elektrofiziológiai vizsgálat során fellépő malignus kamrai ritmuszavar esetén is megfontolandó a készülékbeültetés [5]. Egy 2011-ben publikált, multicentrikus prospektív vizsgálatban 406 DM-beteg utánkövetését végezték. A 9,5 év átlagos utánkövetési periódusban a bevont betegek 15\%-a (62 beteg) esett át vérnyomás-monitorizálás melletti ICDbeültetésen; az ICD-vel élő betegek 14\%-ában jelentkezett malignus kamrai ritmuszavar. A szerzők konklúziója alapján az ICD-implatáció előnyben részesítendő azon betegeknél, akiknél iniciálisan magasabb a hirtelen szívhalál fellépésének, illetve a malignus kamrai ritmuszavarok kialakulásának veszélye [6]. 2016-ban publikált közleményükben Russo és mtsai is ICD-implantáció szükségességét vetették fel DM-ben szenvedő betegpopulációban spontán fellépő vagy invazív elektrofiziológiai vizsgálat során indukált malignus kamrai ritmuszavar esetén [7].

\section{Következtetés}

Betegünk esete rávilágít arra, hogy az invazív elektrofiziológiai vizsgálat fontos módszer a kamrai ritmuszavarok előfordulását tekintve, a magas rizikócsoportba tartozó betegek felismerésére. Ezen betegek azonosítása és ezt követően az ICD beültetése kiemelten fontos a malignus kamrai ritmuszavarokhoz köthető hirtelen szívhalál megelőzése szempontjából.
Anyagi támogatás: A szerzők anyagi támogatásban nem részesültek.

Szerzői munkamegosztás: K. P.: A kézirat megszövegezése, az invazív elektrofiziológiai vizsgálat elvégzése. F. E.: Részvétel az invazív elektrofiziológiai vizsgálatban. D. D.: Irodalomkutatás. P. E.: A kézirat szakmai véleményezése, a neurológiai vizsgálatok elvégzése. F. R.: A szívultrahang-vizsgálat elvégzése, szakmai véleményezés. T. D.: A kézirat megszövegezése. M. F.: Irodalomkutatás. L. E.: A kézirat lektorálása, szakmai véleményezése. V. D.: Részvétel a neurológiai vizsgálatokban. S. T.: A kézirat lektorálása, szakmai véleményezése. A cikk végleges változatát valamennyi szerző elolvasta és jóváhagyta.

Érdekeltségek: A szerzőknek nincsenek érdekeltségeik.

\section{Irodalom}

[1] Theadom A, Rodrigues M, Roxburgh R, et al. Prevalence of muscular dystrophies: a systematic literature review. Neuroepidemiology 2014; 43: 259-268.

[2] Mathieu J, Allard P, Potvin L, et al. A 10-year study of mortality in a cohort of patients with myotonic dystrophy. Neurology 1999; 52: 1658-1662.

[3] Pelargonio G, Dello Russo A, Sanna T, et al. Myotonic dystrophy and the heart. Heart 2002; 88: 665-670.

[4] Groh WJ, Groh MR, Saha C, et al. Electrocardiographic abnormalities and sudden death in myotonic dystrophy type 1. N Engl J Med. 2008; 358: 2688-2697.

[5] Lau JK, Sy RW, Corbett A, et al. Myotonic dystrophy and the heart: a systematic review of evaluation and management. Int J Cardiol. 2015; 184: 600-608.

[6] Bhakta D, Shen C, Kron J, et al. Pacemaker and implantable cardioverter-defibrillator use in a US myotonic dystrophy type 1 population. J Cardiovasc Electrophysiol. 2011; 22: 1369-1375.

[7] Russo V, Rago A, Nigro G. Sudden cardiac death in neuromuscolar disorders: time to establish shared protocols for cardiac pacing. Int J Cardiol. 2016; 207: 284-285.

(Kupó Péter dr., Pécs, Ifjúság út 13., 7624 e-mail: peter.kupo@gmail.com)

A cikk a Creative Commons Attribution 4.0 International License (https://creativecommons.org/licenses/by/4.0/) feltételei szerint publikált Open Access közlemény, melynek szellemében a cikk bármilyen médiumban szabadon felhasználható, megosztható és újraközölhető, feltéve, hogy az eredeti szerző és a közlés helye, illetve a CC License linkje és az esetlegesen végrehajtott módosítások feltüntetésre kerülnek. (SID_1) 